\title{
KUALITAS KUE PUKIS DENGAN SUBSTITUSI TEPUNG KACANG MERAH (Phaseolus vulgaris) DAN TEPUNG BUAH SUKUN (Artocarpus communis) SEBAGAI SUMBER SERAT
}

\author{
THE QUALITY OF PUKIS CAKE WITH SUBSTITUTION OF RED BEAN \\ FLOUR (Phaseolus vulgaris) AND BREADFRUIT FLOUR (Artocarpus \\ communis) AS DIETARY FIBER SOURCE
}

\section{Odelia Yora Chrestella, Franciscus Sinung Pranata, Yuliana Reni Swasti}

Prodi Biologi, Fakultas Teknobiologi, Universitas Atma Jaya Yogyakarta

Jalan Babarsari 44, Yogyakarta 55281

Email: odelia.yora@gmail.com

\begin{abstract}
Pukis cake is a food made with wheat flour as a base. The way to reduce the use of wheat flour in Indonesia is by substituting breadfruit flour (Artocarpus communis) and red bean flour (Phaseolus vulgaris L.). The purpose of substitution is to measure the effect of breadfruit flour and red bean flour substitution on chemistry, physical, microbial, and organoleptic tests in Pukis cake. This study used completely randomized design with variations of breadfruit flour and red bean flour, namely $30 \%$ and $10 \%$ (A); $20 \%$ and $20 \%$ (B); $10 \%$ and $30 \%$ $(C)$; and $0 \%$ (control). The results of this study used ANOVA and Duncan stastitical tests and it showed real evidence on moisture, protein, fat, carbohydrate, crude fiber, soluble fiber content, hardness texture, but did not affect on ash content and microbial test. The best quality of Pukis cake is the substitution with 10\% breadfruit flour and $30 \%$ red bean flour with the results are $42.14 \%$ moisture content, $1.55 \%$ ash content, $7.14 \%$ protein content, $13.30 \%$ fat content, $3587 \%$ carbohydrate content, $11.68 \%$ crude fiber content, $6.57 \%$ soluble fiber content, $261.67 \mathrm{~g}$ of hardness texture, $4.09 \mathrm{log}$ CFU/g of total plate numbers and $2.67 \mathrm{log}$ CFU/g of yeast mold numbers.
\end{abstract}

Keywords: Pukis cake, breadfruit flour, red kidney beans flour, dietary fiber

\begin{abstract}
ABSTRAK
Kue pukis adalah makanan yang dibuat dengan bahan dasar tepung gandum. Cara mengurangi penggunaan tepung gandum di Indonesia yaitu dilakukan substitusi tepung buah sukun (Artocarpus communis) dan tepung kacang merah (Phaseolus vulgaris L.). Tujuan substitusi untuk mengetahui pengaruh substitusi tepung terhadap uji kimia, uji fisik, uji mikrobia dan organoleptik. Metode percobaan yang digunakan pada penelitian ini adalah Rancangan Acak Lengkap dengan variasi tepung buah sukun dan tepung kacang merah yaitu 30\% dan $10 \%$ (A); $20 \%$ dan $20 \%$ (B); $10 \%$ dan 30\% (C); serta 0\% (kontrol). Hasil penelitian dilanjutkan dengan uji statistika menggunakan uji ANOVA dan Duncan. Hasil uji statistik menunjukkan perbedaan nyata pada kadar air, kadar protein, kadar lemak, kadar karbohidrat, kadar serat kasar, kadar serat pangan, tekstur kekerasan, namun tidak berpengaruh pada kadar abu dan uji mikrobia. Pukis kualitas terbaik adalah perlakuan subsitusi $10 \%$ tepung buah sukun dan $30 \%$ tepung kacang merah dengan hasil kadar air 42,14\%, kadar abu $1,55 \%$, kadar protein $7,14 \%$, kadar lemak $13,30 \%$, kadar karbohidrat 35,87\%, kadar serat kasar 11,68\%, kadar serat pangan larut $6,57 \%$. Pukis kualitas terbaik memiliki nilai tekstur kekerasan sebesar 261,67 g, hasil uji mikrobia angka lempeng total 4,09 log koloni/g dan angka kapang khamir 2,67 log koloni/g.
\end{abstract}

Kata kunci: kue pukis, tepung buah sukun, tepung kacang merah, serat pangan 


\section{PENDAHULUAN}

Gandum merupakan bahan pangan yang sering digunakan di Indonesia sebagai bahan pembuat kue, roti, serta olahan makanan lainnya. Pada tahun 2017, impor biji gandum di Indonesia meningkat sekitar $9 \%$ dari tahun-tahun sebelumnya atau sekitar 11.434.134 $\mathrm{kg}$ dengan nilai US\$ 2,65 miliar. Biji gandum diimpor dari negara Australia, Ukraina, Kanada, Amerika Serikat dan negara lainnya (Badan Pusat Statistik, 2020). Salah satu jajanan yang menggunakan tepung gandum sebagai bahan dasar pembuatan makanan adalah kue pukis.

Kue pukis merupakan makanan khas Indonesia yang terbuat dari pencampuran bahan tepung gandum, gula pasir, telur, ragi instan dan santan. Kue pukis memiliki bentuk setengah lingkaran dan adonan yang dituang ke pemanggang sebanyak $3 / 4$ dari dasar cetakan. Penggunaan tepung gandum dalam membuat kue memang penting, namun penggunaan tersebut dapat dikurangi dengan cara melakukan substitusi dengan bahan pangan lain yang dijadikan tepung. Substitusi tersebut tentu saja menggunakan bahan pangan yang memiliki potensi produksi tinggi di Indonesia (Waryat et al. 2014 dan Prasetyan, 2014).
Contoh bahan pangan yang dapat diproduksi di Indonesia adalah kacang merah dan tepung buah sukun. Hasil panen untuk kacang merah di Indonesia pada tahun 2014 dapat mencapai 100.316 ton (Kementerian Pertanian Direktorat Jenderal Hortikultura, 2015), sedangkan buah sukun memiliki hasil panen di tahun 2014 mencapai 103.483 ton (Litbang, 2017). Buah sukun dapat ditemukan di berbagai daerah serta dapat tumbuh sepanjang musim, meskipun demikian buah sukun termasuk buah yang cepat mengalami kerusakan (busuk) (Suprapti, 2002). Oleh karena itu buah sukun diolah menjadi tepung, sehingga dapat meningkatkan masa simpan (Widowati, 2009). Kandungan serat yang terdapat di kacang merah yaitu $6,82 \%$ dan buah sukun yaitu $16,34 \%$ sangat penting dalam mencukupi angka kebutuhan serat perhari (Noviarso, 2009 dan Hayat dkk., 2014).

Kebutuhan serat makanan bagi tubuh orang dewasa berkisar 25-30 gram setiap hari (Rusilanti dan Kusharto, 2007). Serat pangan terdapat di bagian tumbuhan yang dapat dikonsumsi serta tersusun dari karbohidrat dengan struktur polisakarida dan lignin yang tidak dapat dicerna melalui proses hidrolisis dengan bantuan enzim pencernaan di dalam lambung dan usus. Keuntungan dari konsumsi serat 
yang cukup adalah kesehatan organ pencernaan usus terjaga, mencegah penyakit jantung (koroner), mencegah kanker kolon dan sebagai sumber substrat bagi mikrobia usus. Adaya aktivitas fermentasi mikrobia yang menguntungkan di usus, maka suasana menjadi asam, sehingga bakteri patogen dapat dihambat pertumbuhannya. Konsumsi serat juga dapat mencegah penyakit diabetes karena mampu menyerap air dan mengurangi daya cerna karbohidrat, sehingga dapat menghambat kenaikan glukosa darah (Wildman, 2007).

\section{METODOLOGI PENELITIAN}

\section{Waktu dan Tempat Penelitian}

Penelitian dilakukan pada Februari 2019 sampai Agustus 2019 bertempat di Laboratorium Teknobio Pangan dan Laboratorium Produksi dari Fakultas Teknobiologi, Universitas Atma Jaya Yogyakarta.

\section{Alat dan Bahan}

\subsection{Alat-alat}

Peralatan yang dibutuhkan untuk penelitian ini yaitu oven Cosmos CO- 980, grinder Maksindo, ayakan 60 mesh, timbangan analitik Phoenix BTD323, spatula laboratorium, hotplate
Tujuan dilakukan penelitian ini adalah membuat kue pukis yang disubtitusi tepung kacang merah dan tepung buah sukun dengan berbagai konsentrasi. Konsentrasi tepung kacang merah dan tepung buah sukun digunakan ada berbagai macam agar dapat mengetahui konsentrasi terbaik dalam meningkatkan kadar serat pada kue pukis. Hasil penelitian ini juga memberikan informasi kandungan gizi pada kue pukis serta diharapkan dengan adanya substitusi tepung kacang merah dan tepung buah sukun yang tepat dapat mengurangi penggunaan tepung gandum.

Thermo Scientific, kertas saring Whatman 41, waterbath Memmert, cawan moisture balance, moisture balance Phoenix BM-65, labu Kjeldahl, lemari asam BIOBASE, texture analyzer LFRA Brookfield, probe, tanur 1400 Furnace, Laminar Air Flow SV 1200 SG, autoklaf Hirayama Hiclave HVE 50, cawan petri, mikropipet Thermoscientific KH52968, mikrotip, vortex Mixer VM-300, inkubator Memmert.

\subsection{Bahan-bahan}

Bahan yang dibutuhkan untuk membuat kue pukis adalah tepung gandum protein sedang, 
tepung buah sukun (Artocarpus communis) yang diperoleh dari Kusuka Ubiku Bantul, kacang merah (Phaseolus vulgaris) yang diperoleh dari Lingkar Organik Sleman, telur ayam, ragi instan, garam, minyak goreng, gula pasir, santan instan, margarin. Bahan yang digunakan untuk analisis yaitu akuades, larutan heksana, serbuk $\mathrm{Na}_{2} \mathrm{SO}_{4}-\mathrm{HgO}$ (katalisator $\mathrm{N}$ ),

\section{Metode}

\subsection{Pembuatan Tepung dan Uji Kimia Bahan Baku}

Kacang merah kering
disortir kemudian dicuci bersih
setelah itu direndam dalam air
selama 12 jam. Kacang merah
dicuci kembali lalu direbus selama
10 menit selanjutnya, kacang merah
ditiriskan dan didiamkan selama 1
jam. Kacang merah dikeringkan
dalam oven suhu $60^{\circ} \mathrm{C}$ selama 24
jam.

Kacang merah yang telah kering kemudian digiling lalu diayak dengan ayakan 60 mesh dan dikeringkan kembali dalam oven selama 6 jam. Tepung kacang merah disimpan dalam plastik double zip dan dimasukkan dalam toples berisi silika gel. Bahan baku tepung buah sukun dan tepung kacang merah larutan asam sulfat $\left(\mathrm{H}_{2} \mathrm{SO}_{4}\right)$ pekat, larutan $\mathrm{NaOH} 40 \%$, larutan asam borat $\left(\mathrm{H}_{3} \mathrm{BO}_{3}\right) 4 \%$, indikator MR$\mathrm{BCG}$, larutan $\mathrm{HCl} 0,02 \mathrm{~N}$, larutan $\mathrm{H}_{2} \mathrm{SO}_{4} \quad 1,25 \%$, larutan $\mathrm{NaOH}$ $3,25 \%$, serbuk celite, larutan etanol 96\%, medium Plate Count Agar (PCA), medium Potato Dextrose Agar (PDA).

diuji kualitasnya berdasarkan uji kimia meliputi kadar air, kadar abu, kadar protein, kadar lemak, kadar karbohidrat kasar, kadar serat kasar dan kadar serat pangan larut.

\subsection{Metode Penelitian Kue Pukis}

Percobaan dilakukan menggunakan metode Rancangan Acak Lengkap dengan tiga variasi perlakuan tepung buah sukun dan kacang merah yaitu $30 \%$ dan $10 \%$ (A); $20 \%$ dan $20 \%$ (B); $10 \%$ dan $30 \%$ (C). Kue pukis diuji kimia berupa kadar air, kadar abu, kadar protein, kadar lemak, kadar karbohidrat, kadar serat kasar dan serat pangan larut. Kue pukis diuji fisik yang berupa tekstur kekerasan dan diuji mikrobia yang berupa Angka Lempeng Total dan Angka Kapang Khamir. 


\subsection{Pembuatan Kue Pukis}

Tepung gandum 1,25 g, tepung buah sukun 1,625 $\mathrm{g}$ dan tepung kacang merah 1,875 g dicampurkan bersama ragi instan 0,625 g. Selanjutnya, ditambahkan air hangat $13 \mathrm{~mL}$ lalu diaduk rata dan didiamkan selama 20 menit. Telur dan gula $35 \mathrm{~g}$ dicampur hingga mengembang (25 menit). Campuran tepung dan ragi dicampurkan ke dalam telur lalu diaduk salama 5 menit. Tepung gandum $40 \mathrm{~g}$, tepung buah sukun 19 $\mathrm{g}$ dan tepung kacang merah $5 \mathrm{~g}$ dimasukkan bergantian dengan santan sedang $76 \mathrm{~mL}$ lalu diaduk selama 10 menit. Minyak goreng 12 $\mathrm{mL}$ dicampurkan ke dalam bahan lalu diaduk selama 10 menit. Adonan ditutup kain dan didiamkan selama 1 jam.

\section{HASIL DAN PEMBAHASAN}

\section{Analisis Proksimat Bahan Baku}

Tepung buah sukun dan tepung kacang merah merupakan bahan pensubstitusi dalam pembuatan kue pukis. Kedua tepung tersebut
Cetakan kue pukis disiapkan di atas kompor menyala (api kecil) lalu diolesi dengan margarin dan dipanaskan. Adonan diambil sebanyak $20 \mathrm{~mL}$ dengan sendok ukur. Adonan dituangkan ke dalam cetakan kue pukis dan ditutup, lalu dipanggang selama \pm 20 menit (hingga kue pukis matang). Cara yang sama dilakukan untuk kue pukis kontrol, perlakuan B dan perlakuan C. Tahap berikutnya adalah kue pukis masing-masing perlakuan diuji kualitas berdasarkan uji kimia meliputi kadar air, kadar abu, kadar protein, kadar lemak, kadar karbohidrat kasar, kadar serat kasar, kadar serat pangan larut; uji kualitas fisik meliputi tekstur; serta uji kualitas mikrobia meliputi angka lempeng total dan angka kapang khamir.

dilakukan analisis kimia terlebih dahulu. Hasil analisis kimia tepung buah sukun dan tepung kacang merah dapat dilihat pada Tabel 1 dan Tabel 2 di bawah ini. 
Tabel 1. Hasil Analisis Kimia Tepung Buah Sukun

\begin{tabular}{cccc}
\hline Analisis & Hasil Analisis (\%) & Standar Acuan $\mathbf{( \% )}$ & Sumber Acuan \\
\hline Air & 6,90 & 10,82 & (Noviarso, 2003) \\
Abu & 3,07 & 3,42 & (Astuti, 2013) \\
Protein & 2,54 & 4,15 & (Astuti, 2013) \\
Lemak & 1,07 & 1,03 & (Astuti, 2013) \\
Karbohidrat & 86,43 & 89,75 & (Noviarso, 2003) \\
Serat Kasar & 10,47 & 6,51 & (Nugraha, 2016) \\
Serat Pangan Larut & 12,60 & 10,19 & (Daley et al. 2019) \\
\hline
\end{tabular}

Tabel 2. Hasil Analisis Kimia Tepung Kacang Merah

\begin{tabular}{cccc}
\hline Analisis & Hasil Analisis $\mathbf{( \% )}$ & Standar Acuan (\%) & Sumber Acuan \\
\hline Air & 6,62 & 8,35 & (Pangastuti et al. 2013) \\
Abu & 4,77 & 3,08 & (Sutartio, 2018) \\
Protein & 17,40 & 17,86 & (Sutartio, 2018) \\
Lemak & 0,47 & 1,50 & (Astawan, 2009) \\
Karbohidrat & 70,75 & 73,69 & (Sutartio, 2018) \\
Serat Kasar & 10,25 & 6,82 & (Hayat et al. 2014) \\
Serat Pangan Larut & 7,90 & 7,70 & (Cebrejas et al. 2004) \\
\hline
\end{tabular}

Kadar air merupakan salah satu parameter penentu masa simpan (Kusnandar, 2010). Hasil uji kadar air pada tepung buah sukun sebesar 6,90\% (Tabel 1) dan tepung kacang merah sebesar 6,62\% (Tabel 2). Perbedaan kadar air dengan standar acuan dikarenakan adanya perbedaan teknik dalam proses pembuatan tepung. Pada penelitian ini bahan yang telah menjadi tepung dikeringkan kembali pada suhu $60^{\circ} \mathrm{C}$ selama 6 jam, sementara pada penelitian sebelumnya tepung tidak dikeringkan kembali. Hasil penelitian kadar air pada kedua tepung sesuai dengan syarat maksimal 12,5\%, sehingga dapat dinyatakan bahwa tepung aman digunakan selama penyimpanan (Khan dan Shewry, 2009).

Abu atau yang disebut mineral yang terkandung dalam bahan pangan merupakan golongan anorganik dan diperoleh dari hasil sisa pembakaran bahan organik dalam bahan pangan (Sobari, 2018). Hasil uji kadar abu pada tepung buah sukun sebesar 3,07\% (Tabel 1), sedangkan penelitian Astuti (2013), sebesar $3,42 \%$. Kadar abu pada tepung kacang merah sebsar 4,77\% (Tabel 2), sedangkan penelitian Sutartio (2018), sebesar 3,08\%. Perbedaan kadar abu pada tepung buah sukun dan tepung kacang merah dengan penelitian yang lain dikarenakan perbedaan lingkungan hidup, sistem perawatannya seperti pemupukan 
tanaman, perbedaan varietas dan kondisi geografis (Adinugraha dan Kartikawati, 2012; Hayat et al. 2014). Faktor lainnya adalah pada penelitian ini kedua tepung tersebut dikeringkan pada suhu $60^{\circ} \mathrm{C}$ yang dapat menguapkan molekul air pada tepung buah sukun dan tepung kacang merah, sehingga menyebabkan kandungan gizi dan mineral lebih meningkat (Morris et al. 2004).

Protein merupakan kompleks asam amino yang dihubungkan dengan ikatan peptide (Sobari, 2018). Pada Tabel 1, kandungan protein dari tepung buah sukun yang telah dianalisis sebesar 2,54\%, sedangkan penelitian Astuti (2013), sebesar 4,15\%. Adanya perbedaan kadar protein tepung buah sukun dikarenakan umur panen buah sukun yang berbeda. Semakin cepat umur panen buah sukun untuk dijadikan tepung, maka kandungan proteinnya lebih rendah daripada umur panen yang lebih lama (Noviarso, 2003). Pada penelitian ini, buah sukun yang digunakan adalah buah sukun yang belum masak pohon.

Kadar pada protein tepung kacang merah sebesar 17,40\% (Tabel 2) dan hasil tersebut tidak berbeda jauh dari penelitian Sutartio (2018) yaitu 17,86\%. Kacang merah merupakan produk kacang-kacangan yang memang mengandung protein lebih tinggi daripada zat gizi lainnya, maka dari itu kacang merah dapat dijadikan sebagai salah satu sumber protein. Beberapa asam amino esensial yang dominan terkandung dalam kacang merah contohnya berupa leusin $(0,785 \mathrm{~g} / 100 \mathrm{~g})$, lisin $0,670 \mathrm{~g} / 100 \mathrm{~g})$ dan valin $(0,512 \mathrm{~g} / 100$ g) (Margier et al. 2018).

Lemak termasuk golongan lipida yang berbentuk padat pada suhu kamar dan berfungsi salah satunya untuk melarutkan vitamin A, D, E dan K (Sobari, 2018). Pada Tabel 1, kadar lemak tepung buah sukun adalah $1,07 \%$ dan tidak berbeda jauh dari penelitian yang dilakukan oleh Astuti (2013) yaitu 1,03\%. Pada Tabel 2, kadar lemak tepung kacang merah adalah $0,47 \%$, sedangkan penelitian Astawan (2009) adalah $1,50 \%$. Pada penelitian ini bahan dikeringkan dengan oven bersuhu $60^{\circ} \mathrm{C}$ selama 24 jam dan tepung kacang merah dikeringkan dalam oven dengan suhu yang sama selama 6 jam. Lemak pada bahan akan semakin berkurang karena lamanya waktu dan suhu pengeringan, sehingga dapat 
menyebabkan lemak teroksidasi semakin besar pula (Ho et al. 2016).

Karbohidrat dianalisis
dengan metode carbohydrate by
difference atau menghitung
kandungan karbohidrat kasar.
Penentuan carbohydrate by
differencedengan cara mengurangi $100 \%$ dari kadar air, kadar abu, kadar protein, kadar lemak. Hasil analisis kadar karbohidrat yang terkandung dalam tepung buah sukun adalah 86,43\% (Tabel 1), sedangkan hasil analisis kadar karbohidrat tepung kacang merah adalah 70,75\% (Tabel 2). Golongan karbohidrat tertinggi yang ada pada daging buah sukun adalah sukrosa (1,38\%) (Adewusi et al. 1995).

Serat kasar merupakan komponen residu yang tidak dapat dihidrolisis menggunakan asam kuat dan basa kuat, misalnya hemiselulosa, selulosa dan lignin (Wildman, 2007). Hasil analisis kadar serat kasar pada tepung buah sukun adalah $10,47 \%$ (Tabel 1), sedangkantepung kacang merah adalah 10,25\% (Tabel 2). Perbedaan kadar serat pada bahan baku dibandingkan penelitian sebelumnya dikarenakan perbedaan umur bahan pangan yang dipakai.
Menurut Noviarso (2003), buah yang berumur lebih muda akan menghasilkan serat lebih banyak daripada buah masak. Sebagian besar serat kasar yang terkandung dalam buah sukun berupa lignin $(4,32 \%)$, selulosa $(9,67 \%)$ dan hemiselulosa (29\%) (Appiah et al. 2012), sedangkan serat kasar dalam kacang merah sebagian besar berupa selulosa (2,5-5,9\%), lignin $(2,7-3,1 \%)$ dan hemiselulosa $(0,3 \%)$ (Tiwari et al. 2011).

Serat pangan merupakan karbohidrat yang terdapat dalam tanaman yang tahan terhadap proses pencernaan dan penyerapan di usus kecil (American Association of Cereal Chemist, 2001). Hasil analisis kadar serat pangan larut dari tepung buah sukun adalah 12,60\% (Tabel 1), sedangkan tepung kacang merah sebesar 7,90\% (Tabel 2). Tepung buah sukun (Artocarpus camansi) mengandung serat pangan larut berupa pektin $(1,95 \%)$ dan gum $(0,40 \%)$ sedangkan $89,25 \%$ serat pangan tidak larut (Suryanti et al. 2017). Serat pangan larut yang terkandung dalam kacang merah berupa pektin sebesar 2,3\%bk (Khan et al. 2007). 


\section{Karakteristik Kue Pukis}

\section{berdasarkan Analisis Kimia}

Berdasarkan hasil analisis

kimia dari kue pukis maka didapatkan hasil kadar air, kadar abu, kadar protein, kadar lemak kadar karbohidrat, kadar serat kasar dan kadar serat pangan larut. Hasil analisis kimia kue pukis dapat dilihat di Tabel 3 di bawah ini.

Tabel 3. Hasil Analisis Kimia pada Kue Pukis

\begin{tabular}{cccccccc}
\hline Perlakuan & $\begin{array}{c}\text { Air } \\
(\%)\end{array}$ & $\begin{array}{c}\text { Abu } \\
(\%)\end{array}$ & $\begin{array}{c}\text { Protein } \\
(\%)\end{array}$ & $\begin{array}{c}\text { Lemak } \\
(\%)\end{array}$ & $\begin{array}{c}\text { Karbohi } \\
\text { drat }(\%)\end{array}$ & $\begin{array}{c}\text { Serat } \\
\text { Kasar } \\
(\%)\end{array}$ & $\begin{array}{c}\text { Serat Pangan } \\
\text { Larut }(\%)\end{array}$ \\
\hline \multirow{2}{*}{$\mathrm{K}$} & $44,01 \pm$ & $1,39 \pm$ & $5,94 \pm$ & $11,35 \pm$ & $37,30 \pm$ & $8,29 \pm$ & $4,67 \pm 0,83^{\mathrm{a}}$ \\
& $0,86^{\mathrm{b}}$ & $0,18^{\mathrm{a}}$ & $0,15^{\mathrm{b}}$ & $0,06^{\mathrm{a}}$ & $0,90^{\mathrm{b}}$ & $1,29^{\mathrm{a}}$ & \\
$\mathrm{A}$ & $43,85 \pm$ & $1,23 \pm$ & $5,36 \pm$ & $11,39 \pm$ & $38,18 \pm$ & $10,66 \pm$ & $4,08 \pm 0,27^{\mathrm{a}}$ \\
& $0,09^{\mathrm{b}}$ & $0,25^{\mathrm{a}}$ & $0,27^{\mathrm{a}}$ & $0,06^{\mathrm{a}}$ & $0,47^{\mathrm{b}}$ & $0,81^{\mathrm{b}}$ & \\
$\mathrm{B}$ & $43,22 \pm$ & $1,28 \pm$ & $6,25 \pm$ & $12,14 \pm$ & $37,10 \pm$ & $12,45 \pm$ & $4,56 \pm 0,05^{\mathrm{a}}$ \\
& $0,24^{\mathrm{b}}$ & $0,07^{\mathrm{a}}$ & $0,23^{\mathrm{b}}$ & $0,15^{\mathrm{b}}$ & $0,22^{\mathrm{b}}$ & $0,63^{\mathrm{c}}$ & \\
$\mathrm{C}$ & $42,14 \pm$ & $1,55 \pm$ & $7,14 \pm$ & $13,30 \pm$ & $35,87 \pm$ & $11,68 \pm$ & $6,57 \pm 0,35^{\mathrm{b}}$ \\
& $0,48^{\mathrm{a}}$ & $0,13^{\mathrm{a}}$ & $0,08^{\mathrm{c}}$ & $0,59^{\mathrm{c}}$ & $0,62^{\mathrm{a}}$ & $0,36^{\mathrm{bc}}$ & \\
\hline
\end{tabular}

Keterangan:

- Huruf notasi yang berbeda pada kolom menunjukkan adanya beda nyata pada taraf signifikasi $\alpha=5 \%$ dengan tingkat kepercayaan $95 \%$

- Huruf K adalah tanpa substitusi tepung kacang merah dan tepung buah sukun

- Huruf A adalah perbandingan $60 \%$ tepung gandum : $30 \%$ tepung buah sukun : $10 \%$ tepung kacang merah

- Huruf B adalah perbandingan $60 \%$ tepung gandum : $20 \%$ tepung buah sukun : $20 \%$ tepung kacang merah

- Huruf C adalah perbandingan $60 \%$ tepung gandum : $10 \%$ tepung buah sukun : $30 \%$ tepung kacang merah

\subsection{Kadar Air}

Hasil kadar air kue pukis antara $42,14-44,01 \%$ dan menunjukan bahwa seiring penambahan tepung kacang merah maka kadar air terus menurun (Tabel 3). Hal itu dikarenakan pada uji bahan baku, tepung kacang merah memiliki kadar air yang lebih rendah daripada tepung buah sukun. Penurunan kadar air sesuai dengan penelitian Rakhmawati et al. (2014), yaitu substitusi tepung kacang merah akan menurunkan kadar air pada produk flakes. Menurut Kusnandar (2010), air akan berikatan dengan gugus karboksil dari asam amino, sehingga semakin banyak kacang merah yang digunakan maka semakin banyak pula gugus karboksil yang mampu mengikat air. Hal lain dikarenakan adanya serat berukuran polimer besar, struktur yang kompleks dan juga memiliki gugus hidroksil serta struktur matriks yang berlipat dari 
serat akan berikatan dengan gugus hidroksil bebas dari air.

Hasil kadar abu kue pukis antara 1,23-1,55\% dan menunjukan tidak ada beda nyata untuk setiap perlakuan berdasarkan analisis statistik (Tabel 1). Hasil uji kadar abu pada kue pukis sesuai dengan penelitian yang dilakukan oleh Manonmani et al. (2014), yaitu kadar abu roti yang disubstitusi tepung kacang merah berkisar 1,30$1,60 \%$. Kadar abu yang tinggi disebabkan kandungan mineral yang terdapat di dalam bahan tepung

\subsection{Kadar Protein}

Kadar protein pada kue pukis antara 5,36-7,14\% dan seiring penambahan tepung kacang merah maka kadar protein meningkat (Tabel 3). Kadar protein kue pukis tertinggi pada substitusi tepung kacang merah 30\%. Hasil uji kadar protein kue pukis telah sesuai dengan Manonmani et al. (2014), yaitu seiring penambahan konsentrasi tepung kacang merah pada roti maka kadar protein roti

\subsection{Kadar Lemak}

Kadar lemak pada kue pukis berkisar 11,35-13,30\% dan cenderung meningkat seiring dengan peningkatan substitusi

\subsection{Kadar Abu}

buah sukun dan tepung kacang merah. Mineral tertinggi pada kacang merah kering yaitu 762,7 mg Magnesium (Hayat et al. 2014), sedangkanpada buah sukun yaitu 376,7 mg Kalium (Ragone, 2014). Dampak kelebihan magnesium dalam tubuh mengakibatkan gagal ginjal, sedangkan kalium akan mengganggu tekanan osmotik dalam cairan intraseluler (Haroen, 2008 dan Winarno, 1997).

tersebut akan meningkat. Adanya peningkatan kadar protein dikarenakan kacang merah memiliki kadar protein yang lebih tinggi daripada tepung buah sukun pada hasil uji bahan baku. Menurut Sutartio (2018), tepung kacang merah memiliki kadar protein sebesar $17,86 \%$, sedangkan menurut Noviarso (2003), tepung buah sukung memiliki protein sebesar $5,57 \%$.

tepung kacang merah (Tabel 3). Kadar lemak kue pukis pada penelitian ini sesuai dengan penelitian yang dilakukan oleh 
Manonmani et al. (2014), yaitu seiring penambahan konsentrasi tepung kacang merah pada roti maka kadar lemak roti tersebut akan meningkat. Kadar lemak tertinggi pada perlakuan $\mathrm{C}$, hal itu disebabkan tingginya kadar protein pada perlakuan tersebut. Pada umumnya protein memiliki gugus

\subsection{Kadar Karbohidrat}

Penentuan kadar karbohidrat pada penelitian dihitung dengan metode carbohydrate by difference yaitu persentase karbohidrat $100 \%$ dikurangi dengan persentase dari kadar air, abu, lemak dan protein (Sobari, 2017). Hasil kadar karbohidrat kue pukis antara 35,87$38,18 \%$ dan seiring dengan penambahan tepung buah sukun maka karbohidrat semakin meningkat (Tabel 3). Pada hasil uji bahan baku, karbohidrat yang terkandung dalam buah sukun lebih

\subsection{Kadar Serat Kasar dan Serat Pangan Larut}

\section{a. Serat Kasar}

Hasil uji kadar serat kasar kue pukis antara 8,29-12,45\%. Hasil uji kadar serat kasar kue pukis perlakuan A ternyata lebih rendah dibandingkan perlakuan lainnya, sedangkan pada uji bahan awal hidrofobik, sehingga mampu mengikat lipid (lipoprotein). Kadar protein yang tinggi dari kacang merah mampu mengikat lemak dari santan dan minyak goreng, oleh sebab itu kadar lemak pada perlakuan $\mathrm{C}$ adalah paling tinggi (Kusnandar, 2010).

tinggi dibandingkan kacang merah, maka dari itu seiring penambahan tepung buah sukun maka kadar karbohidrat juga meningkat. Menurut Noviarso (2003), tepung buah sukun memiliki kadar karbohidrat sebesar $88,83 \%$ dan menurut Rakhmawati et al. (2014), tepung kacang merah memiliki kadar karbohidrat sebesar 70,33\%. Karbohidrat buah sukun berasal dari kandungan pati yang berubah menjadi gula pereduksi.

tepung sukun memiliki kadar serat kasar yang lebih tinggi daripada tepung kacang merah. Penurunan kadar serat kasar pada kue pukis perlakuan A dimungkinkan adanya pemecahan serat kasar berupa 
hemiselulosa ataupun selulosa oleh ragi yang memiliki enzim hemiselulase ataupun enzim selulase. Perombakan tersebut akan menghasilkan xilosa ataupun glukosa sebagai kebutuhan hidup mikrobia (Amarasekara, 2013). Jenis serat kasar pada kacang merah berupa selulosa $(2,5-5,9 \%)$, lignin $(2,7-3,1 \%)$ dan hemiselulosa $(0,3 \%)$ (Tiwari et al. 2011), sedangkan pada buah sukun berupa hemiselulosa $(29 \%)$, selulosa $(9,67 \%)$, dan lignin (4,32 \%) (Appiah et al. 2012).

Kadar serat kue pukis pada penelitian ini lebih tinggi dari kadar serat kue pukis menurut penelitian Prasetyan (2014), yaitu 2,66\% dan Holidya (2019), yaitu 2,96\%. Pada penelitian ini sumber serat berasal dari kedua tepung yaitu tepung buah sukun dan tepung kacang merah.

\section{b. Serat Pangan Larut}

Kadar serat pangan larut pada kue pukis perlakuan adalah $4,08-6,57 \%$. Pengaplikasian tepung sukun dengan konsentrasi tertinggi pada kue pukis perlakuan A ternyata hasil kadar serat pangan larut lebih rendah dibandingkan kadar serat pangan larut kue pukis perlakuan C. Penurunan kadar serat larut perlakuan A dimungkinkan
Pada penelitian Prasetyan (2014) dan Holidya (2019), sumber serat hanya berasal dari tepung mocaf (singkong).

Konsumsi kue pukis yang memiliki kandungan serat yang diharapkan mampu mengurangi gangguan pada sistem pencernaan. Menurut Mandhu et al. (2017), buah-buahan yang berserat memiliki aktivitas pencahar pada tikus percobaan dan feses pada tikus percobaan mengandung serat kasar. Menurut American Association of Cereal Chemist (2001) dan Surampudi et al. (2016), serat tidak dapat dicerna oleh sistem pencernaan dan penyerapan di usus, namun dapat meningkatkan konsistensi dan massa feses.

mikrobia lebih memanfaatkan serat pangan dari tepung buah sukun daripada tepung kacang merah. Hal tersebut dibuktikan dengan hasil uji ALT dan AKK kue pukis perlakuan A lebih tinggi daripada perlakuan $C$. Pada penelitian yang dilakukan oleh Suryanti et al. (2017), menunjukkan bahwa serat pangan yang terkandung dalam buah sukun 
Artocarpus camansi adalah 89,25\% serat pangan tidak larut, sementara itu serat pangan larut yang teruji adalah $1,95 \%$ pektin dan $0,40 \%$ gum.

Anjuran konsumsi serat yaitu pada usia 16 tahun ke atas dianjurkan konsumsi serat sebanyak 30 g/harinya (Hooper et al. 2015). Serat pangan larut dijadikan substrat bagi Lactobacillus brevis dan Lactobacillus plantarum di usus, sehingga mampu menghambat senyawa karsinogen (Utama et al. 2018). Bakteri dapat menghasilkan asam lemak rantai pendek contohnya butirat (SCFA), yang berfungsi untuk melindungi sel-sel usus dari kerusakan DNA, menghambat proliferasi sel kanker (Raman et al. 2016). Penurunan kolesterol, menurunkan pengosongan lambung dan waktu transit di usus kecil disebabkan karena konsumsi serat pangan. Kemampuan serat pangan mengikat glukosa dan air, sehingga daya cerna glukosa tetap terkontrol dan feses tidak keras (Pozuelo et al. 2012; Surampudi et al. 2016 dan Kusharto, 2006).

\section{Karakteristik Kue Pukis berdasarkan Analisis Fisik}

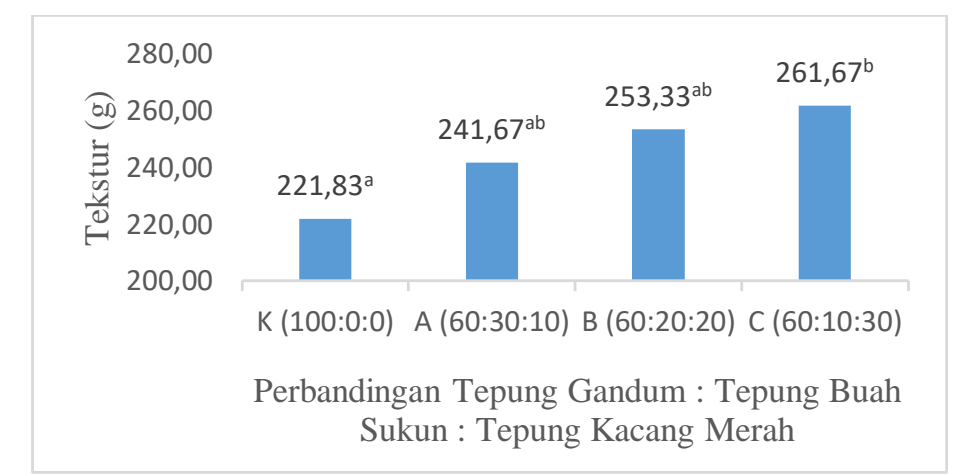

Gambar 1. Nilai Tekstur Kekerasan pada Kue Pukis dengan Substitusi Tepung Buah Sukun dan Tepung Kacang Merah

Berdasarkan grafik di atas (Gambar 1), dapat dilihat bahwa perlakuan $\mathrm{K}$ atau tanpa substitusi tepung buah sukun dan tepung kacang merah memiliki tekstur yang lunak. Hal tersebut dikarenakan protein gluten dari tepung gandum membantu pelunakan kue pukis. Gluten terbentuk dari gabungan gliadin dan glutenin yang saling larut dalam air ketika air ditambahkan ke dalam adonan roti. Pada adonan roti, gluten berfungsi untuk mengikat pati dan gas, sehingga membuat adonan roti 
menjadi mengembang, empuk dan berongga. Oleh sebab itu kue pukis perlakuan $\mathrm{K}$ memiliki tingkat kekerasan yang lebih kecil (lunak) daripada perlakuan lainnya (deMan, 1997 dan Kusnandar, 2010).

Kue pukis perlakuan $\mathrm{C}$ adalah yang memiliki tekstur yang keras dan hasil ini sesuai dengan penelitian yang dilakukan oleh Manonmani et al. (2014), yaitu semakin tinggi penambahan tapung kacang merah pada adonan roti maka akan membuat tekstur roti semakin keras. Pada perlakuan $\mathrm{C}$ tekstur dari kue pukis pukis masih dapat diterima oleh 30 panelis. Menurut Manonmani et al.
(2014), kekerasan tekstur roti yang disubstitusi tepung kacang merah maksimal $10.051 \mathrm{~g}$.

Kue pukis yang semakin keras disebabkan serat pangan dari tepung kacang merah. Pada hasil analisis serat pangan larut di kue pukis perlakuan $\mathrm{C}$ adalah yang paling tinggi (Tabel 3), sehingga mampu mengikat air lebih banyak. Hal ini dibuktikan pada adonan kue pukis perlakuan $\mathrm{C}$ memiliki viskositas yang lebih tinggi. Serat pangan akan bersaingan dengan pati untuk mengikat air, sehingga dapat menurunkan kelembutan roti dan menurunkan volume roti (Rosell et al. 2010 dan Dhingra et al. 2012).

\section{Karakteristik Kue Pukis berdasarkan Analisis Mikrobia}

Tabel 4. Hasil Mikrobia pada Kue Pukis dengan Substitusi Tepung Buah Sukun dan Tepung Kacang Merah

\begin{tabular}{ccc}
\hline Perlakuan & Angka Lempeng Total $(\log \mathbf{C F U} / \mathbf{g})$ & Angka Kapang Khamir $(\log \mathbf{C F U} / \mathbf{g})$ \\
\hline $100: 0: 0(\mathrm{~K})$ & $4,38 \pm 0,61^{\mathrm{a}}$ & $3,73 \pm 0,45^{\mathrm{a}}$ \\
$60: 30: 10(\mathrm{~A})$ & $4,08 \pm 0,52^{\mathrm{a}}$ & $4,16 \pm 1,01^{\mathrm{a}}$ \\
$60: 20: 20(\mathrm{~B})$ & $3,82 \pm 0,19^{\mathrm{a}}$ & $2,47 \pm 2,14^{\mathrm{a}}$ \\
$60: 10: 30(\mathrm{C})$ & $4,09 \pm 0,38^{\mathrm{a}}$ & $2,67 \pm 2,34^{\mathrm{a}}$ \\
\hline Keterangan: & Huruf notasi yang berbeda pada kolom menunjukkan adanya beda nyata pada \\
& taraf signifikasi $\alpha=5 \%$ dengan tingkat kepercayaan 95\%
\end{tabular}

Faktor penentu kualitas kue pukis layak untuk dikonsumsi adalah banyaknya cemaran mikrobia yang terkandung di dalamnya. Cara untuk mengetahui banyaknya jumlah mikrobia yang mungkin tumbuh pada kue pukis adalah pengujian menggunakan metode Angka
Lempeng Total (ALT) dengan cara pour plate di media plate count agar (PCA) (Fardiaz, 1992).

Angka lempeng total pada kue pukis berkisar 3,82-4,38 $\log \mathrm{CFU} / \mathrm{g}$. Hasil pengujian angka lempeng total sesuai dengan standar SNI Roti Manis 01-3840-1995 yaitu maksimal $6 \log$ 
$\mathrm{CFU} / \mathrm{g}$. Hasil ALT kue pukis berada di bawah standar SNI, sehingga dapat dikatakan bahwa kue pukis pada penelitian ini layak untuk dikonsumsi. Banyaknya mikrobia pada setiap perlakuan dikarenakan mikrobia memanfaatkan ketersediaan bahan makanan yang ada di dalam kue pukis.

Mikrobia mampu memanfaatkan kandungan gula yang berasal dari bahan gula pasir, tepung buah sukun, tepung gandum. Selain itu, mikrobia juga memanfaatkan protein yang berasal dari telur dan tepung kacang merah. Faktor lain yang mendukung pertumbuhan mikrobia adalah aktivitas air pada kue pukis. Hal tersebut dibuktikan dengan keterkaitan kadar air kue pukis perlakuan A (Tabel 1) adalah yang paling tinggi, sehingga mikrobia pada kue pukis perlakuan A lebih banyak tumbuh dibandingkan dengan perlakuan lainnya. Aktivitas air diperoleh dari air bebas yang terdapat di makanan, sehingga menjadi media pertumbuhan oleh mikrobia (Winarno, 1997).

Kapang dan khamir tergolong fungi, perbedaan yang dapat diamati secara makroskopis yaitu pada kapang tumbuh hifa, sedangkan khamir tidak (Fifendy dan Biomed, 2017). Pengujian kapang dan khamir pada kue pukis menggunakan metode spread plate di atas medium potato dextrose agar (PDA) yang telah memadat (King, 1986).

Kapang dan khamir pada kue pukis berkisar 2,47-4,16 $\log \mathrm{CFU} / \mathrm{g}$. Hasil pengujian kapang dan khamir sesuai dengan standar SNI Roti Manis 01-3840-1995 yaitu maksimal 4 log $\mathrm{CFU} / \mathrm{g}$. Hasil uji kapang dan khamir kue pukis berada di bawah standar SNI, sehingga dapat dikatakan bahwa kue pukis pada penelitian ini layak untuk dikonsumsi.

Hasil uji kapang dan khamir menunjukkan bahwa mikroorganisme tersebut lebih banyak tumbuh di kue pukis perlakuan A (Tabel 2). Hasil tersebut sejalan dengan kadar karbohidrat kue pukis perlakuan A adalah yang tertinggi (Tabel 1). Menurut Fifendy dan Biomed (2017), karbohidrat yang ada di kue pukis dimanfaatkan oleh kapang dan khamir untuk media pertumbuhan. Kapang dan khamir memanfaatkan gula dari karbohidrat tepung buah sukun sebagai substrat yang nantinya akan menghasilkan alkohol dan $\mathrm{CO}_{2}$. 


\section{Hasil Uji Organoleptik Kue Pukis}

Organoleptik adalah pengujian produk pangan menggunakan kemampuan indera manusia berupa penglihatan (mata), penciuman (hidung) dan perasa (lidah) sebagai daya ukur penerimaan suatu produk (Kusuma dkk, 2017).
Parameter yang diamati pada uji organoleptik kue pukis yaitu warna, rasa, aroma dan tekstur. Hasil organoleptik pada kue pukis yang disubstitusi dengan tepung buah sukun dan tepung kacang merah terdapat pada Tabel 5 di bawah ini.

Tabel 5. Hasil Organoleptik Kue Pukis dengan Substitusi Tepung Buah Sukun dan Tepung Kacang Merah

\begin{tabular}{lcccccc}
\hline Perlakuan $(\%)$ & Warna & Aroma & Rasa & Tekstur & Rerata & Peringkat \\
\hline $100: 0: 0(\mathrm{~K})$ & 2,70 & 2,43 & 2,37 & 2,53 & 2,51 & 3 \\
$60: 30: 10(\mathrm{~A})$ & 2,37 & 1,97 & 1,87 & 1,87 & 2,02 & 4 \\
$60: 20: 20(\mathrm{~B})$ & 2,97 & 3,00 & 3,17 & 3,23 & $\mathbf{3 , 0 9}$ & $\mathbf{1}$ \\
$60: 10: 30(\mathrm{C})$ & 2,10 & 2,77 & 2,83 & 2,57 & 2,57 & 2 \\
\hline
\end{tabular}

Pada Tabel 5 di atas menunjukkan bahwa warna kue pukis yang paling disukai oleh panelis adalah kue pukis perlakuan B dengan jumlah penilaian 2,97. Warna yang terbentuk pada kue pukis yang disubstitusi tepung buah sukun dan tepung kacang merah adalah cokelat. Warna cokelat terbentuk karena kandungan protein dari kacang merah yang memiliki gugus amin bereaksi dengan gula reduksi (Kusnandar, 2010). Menurut penelitian Praptiningrum (2015), substitusi tepung kacang merah dan tepung gandum yang digunakan dalam pembuatan cookies. Berdasarkan aspek warna yang terbaik adalah tepung kacang merah $70 \%$ dan tepung gandum $30 \%$.
Aroma yang paling disukai adalah kue pukis perlakuan B dengan penilaian 3,00. Hasil ini sejalan dengan penelitian yang dilakukan oleh Sunarwati (2011), brownies kukus substitusi tepung sukun hingga $45 \%$ adalah yang terbaik berdasarkan aspek warna, aroma, rasa dan tekstur. Semakin meningkatnya substitusi tepung buah sukun, aroma kue pukis menjadi tidak disukai oleh panelis yaitu kue pukis perlakuan A. Menurut Suprapti (2002), sukun yang belum masak akan menghasilkan cita rasa yang kurang enak dibandingkan sukun masak.

Rasa yang paling disukai adalah kue pukis perlakuan B dengan penilaian 3,17. Rasa yang direspon oleh indera pengecap adalah rasa 
manis yang berasal dari kandungan karbohidrat dari tepung buah sukun dan tepung kacang merah selain itu adanya penambahan gula pasir pada pembuatan adonan. Rasa yang paling tidak disukai adalah kue pukis perlakuan A. Pada perlakuan tersebut tepung buah sukun yang digunakan adalah buah mengkal. Buah sukun yang mengkal memiliki rasa dan aroma yang tidak seenak buah masak pohon. Aroma dan rasa tersebut akan direspon oleh papilla lidah dan sistem olfaktori (Kemp dkk., 2009).

Tekstur yang paling disukai adalah kue pukis perlakuan $B$ dengan penilaian 3,23, sedangkan perlakuan A paling tidak disukai dengan penilaian 1,87. Tekstur kue pukis dipengaruhi oleh kadar serat dari tepung buah sukun dan tepung kacang merah. Penambahan serat dapat penurunan kualitas dan efek viskositas adonan (Stojceska dalam Preedy dan Patel, 2011). Viskositas adonan yang tinggi akan

\section{DAFTAR PUSTAKA}

Adewusi, S. R. A., Udio, J. dan Osuntogun, B. A. 1995. Studies on the carbohydrate content of breadfruit (Artocarpus communis Forst) from South-Western Nigeria. Starch 47(8): 289-294.

Adinugraha, H. A. dan Kartikawati, N. K. 2012. Variasi morfologi dan kandungan gizi buah sukun. Wana Benih 13(2): 99-106. menyebabkan kue tidak dapat mengembang sempurna, sehingga menghasilkan tekstur yang keras dan tidak disukai oleh panelis. Serat pangan dapat menurunkan kelembutan roti, namun karena serat mampu menyerap air, sehingga bahan-bahan lain dapat ikut tercampur (Dhingra dkk., 2012).

\section{KESIMPULAN}

Variasi konsentrasi tepung buah sukun dan tepung kacang merah yang disubstitusikan memberikan pengaruh terhadap kualitas kue pukis yaitu kadar air, kadar protein, kadar lemak, kadar karbohidrat, kadar serat kasar, kadar serat pangan larut, tekstur kekerasan, namun tidak memberikan pengaruh terhadap kadar abu, angka lempeng total, angka kapang khamir. Kue pukis yang disubstitusi tepung buah sukun $10 \%$ dan tepung kacang merah $30 \%$ menghasilkan kualitas terbaik berdasarkan uji kimia, fisik dan mikrobia.

Amarasekara, A.S. 2013. Handbook of Cellulosic Ethanol. Wiley. Canada.

American Association of Cereal Chemist. 2001. The Definition of Dietary Fiber. Cereal Foods World.

Appiah, F., Ellis, W. O. dan Oduro, I. 2012. Predicting the digestibility of nutrients and energy values of 4 breadfruit varieties based on chemical analysis. Pakistan Journal of Nutrition 11(4): 401-405. 
Astawan, M. 2009. Sehat dengan Hidangan Kacang dan Biji-bijian. Penebar Swadaya. Jakarta.

Astuti, T. Y. I. 2013. Substitusi tepung sukun dalam pembuatan non flaky crackers bayam hijau (Amaranthus tricolor). Naskah Skripsi S-1. Fakultas Teknobiologi Universitas Atma Jaya Yogyakarta, Yogyakarta.

Badan Pusat Statitstik. 2020. Impor biji gandum dan meslin menurut negara asal utama, 2010-2018.

https://www.bps.go.id/statictable/2019/0 2/14/2016/impor-biji-gandum-danmeslin-menurut-negara-asal-utama2010-2018.html [Diakses pada tanggal 22 Februari 2020].

Cebrejas, M. A. M., Sanfiz, B., Vidal, A., Molla, E., Esteban, R. dan Andreu, F. J. L. 2004. Effect of fermentation and autoclaving on dietary fiber fractions and antinutritional factors of beans (Phaseolus vulgaris L.). Journal of Agricultural and Food Chemistry 52: 261-266.

Chang, R. 2005. Kimia Dasar edisi ketiga jilid 1. Erlangga. Jakarta.

Daley, O. O., Robert-Nkrumah, L. B., Alleyne, A. T., Francis, G. I., Broomes, J. dan Badrie, N. 2019. Assessment of breadfruit (Artocarpus altilis, Parkinson) cultivitas for resistant starch, dietary fiber, and energy density. Afr. J. Food Agric. Nutr. Dev 19(4): 15060-15076.

DeMan, J. M. 1997. Kimia Makanan edisi ke-2. ITB Press. Bandung.

Dhingra, D., Michael, M., Rajput, H. dan Patil, R. T. 2012. Dietary fibre in foods. Journal Food Science Technology 49(3): 255266.

Technology 49(3): 255-266.

Fardiaz, S. 1992. Mikrobiologi Pangan 1. Gramedia Pustaka Utama. Jakarta.

Fifendy, M. dan Biomed, M 2017. Mikrobiologi. Kencana. Depok.

Haroen, H. 2008. Teknik Prosedural Keperawatan: Konsep dan Aplikasi Kebutuhan Dasar Klien Asmadi. Salemba Medika. Jakarta.

Hayat, I., Ahmad, A., Ahmed, A., Khalil, S. dan Gulfraz, M. 2014. Exploring the potential of red kidney beans (Phaseolus vulgaris L.) to develop protein based product for food applications. Journal of Animal \& Plant Science 24 (3).

Ho, L. H., Suhaimi, M. A., Ismail, I. dan Mustafa, K. A. 2016. Effect of different drying conditions on proximate compositions of red and yellow-fleshed watermelon rind powder. Journal Agrobiotech 7: 1-12.
Holidya, N. 2019. Pengaruh substitusi tepung mocaf (modified cassava flour) dan penambahan puree daun kelor (Moringa oleifera) terhadap sifat organoleptik kue puks. Jurnal Tata Boga 8(3): 439-447.

Hooper, B., Spiro, A. dan Stanner, S. 2015. $30 \mathrm{~g}$ of fibre a day: an achievable recommendation?. Nutrition Bulletin 40: 118-129.

Kementerian Pertanian Direktorat Jenderal Hortikultura. 2015. Statistik produksi hortikultura tahun 2014. http://hortikultura.pertanian.go.id/wpcontent/uploads/2016/02/Statistik-

Produksi-2014.pdf [Diakses pada 25 September 2019].

Kemp, S. E., Hollowood, T. dan Hort, J. 2009. Sensory Evaluation: A Practical Handbook. Wiley Blackwell, London.

Khan, A. R., Alam, S., Ali, S., Bibi, S. dan Khalil, I. A. 2007. Dietary fiber profile of food legumes. Journal of Agriculture 23(3): 763-766.

Khan, K. dan Shewry, P. R. 2009. Wheat Chemistry and Technology $4^{\text {th }}$ edition. AACC International. Minnesota.

King, A. D. Jr., Pitt, J. I., Beuchat, L. R. dan Corry J, E. L. 1986. Methods for The Mycological Examination of Food. Plenum Press. New York.

Kusharto, C. M. 2006. Serat makanan dan peranannya bagi kesehatan. Jurnal Gizi dan Pangan 1(2): 45-54.

Kusnandar, F. 2010. Kimia Pangan: Komponen Makro. DIAN RAKYAT. Jakarta.

Kusuma, T. S., Kurniawati, A. D., Rahmi, Y., Rusdan, I. H., Widyanto, R. M. 2017. Pengawasan Mutu Makanan. Universitas Brawijaya Press, Malang.

Litbang. 2017. Tepung sukun gantikan $75 \%$ tepung terigu. http://www.litbang.pertanian.go.id/infoteknologi/2813/ [Diakses pada 25 Meret 2018].

Mandhu, C., Krishna, K. M., Reddy, K. R., Lakshmi, P. J. dan Kelari, E. K. 2017. Estimation of crude fibre content from natural food stuffs and its laxative activity induced in rats. Int. Journal Pharma Res. Health Science 5(3): 1704.

Manonmani, D., Bhol, S. dan Bosco, S. J. D. 2014. Effect of red kidney bean (Phaseolus vulgaris L.) flour on bread quality. Open Access Library Journal 1: 1-6.

Margier, M., Hafnaoui, N., George, S. dan Remond, D. 2018. Nutritional composition and bioactive content of legumes: characterization of pulses frequently consumed in france and effect 
of cooking method. Nutrients 10 (11): 1668.

Morris, A., Barnett, A. dan Burrows, O. 2004. Effect of processing on nutrient content of foods. Cajarticles 37: 160-164.

Noviarso, C. 2003. Pengaruh umur panen dan masa simpan buah sukun (Artocarpus altilis) terhadap kualitas tepung sukun yang dihasilkan. Naskah Skripsi S-1. Fakultas Teknologi Pertanian Institute Pertanian Bogor, Bogor.

Nugraha. Y. A. 2016. Kualitas non flaky crackers dengan substitusi tepung sukun dan tepung ikan teri nasi (Stolephorus sp.). Naskah Skripsi S-1. Fakultas Teknobiologi Universitas Atma Jaya Yogyakarta, Yogyakarta.

Pangastuti, H. A., Affandi, D. R. dan Ishartani, D. 2013. Karakterisasi sifat fisik dan kimia tepung kacang merah (Phaseolus vulgaris L.) dengan beberapa perlakuan pendahuluan. Jurnal Teknosains Pangan 2 (1): 26.

Pozuelo, M. J., Torres, A. A., Hernandez, D. H., Oliva, M. E. L., Martinez, R. R. dan Goni, I. 2012. Grape antioxidant dietary fiber stimulates Lactobacillus growth in rat cecum. Journal of Food Science 77(2): 59-62.

Praptiningrum, W. 2015. Eksperimen pembuatan butter cookies tepung kacang merah substitusi tepung terigu. Naskah Skripsi $S$-1. Fakultas Teknik Universitas Negeri Semarang, Semarang.

Prasetyan, L. 2014. Pengaruh substitusi mocaf (modified cassava flour) dan penambahan wortel (Daucus carrota) terhadap hasil jadi kue pukis. Jurnal Boga 3(1): 284.

Ragone, B. 2014. Breadfruit Nutritional Value and Versatility. State of Hawai'i Departement of Agriculture.

Rakhmawati, N., Amanto, B. S. dan Praseptiangga, D. 2014. Formulasi dan evaluasi sifat sensoris dan fisikokimia produk flakes komposit berbahan dasar tepung tapioka, tepung kacang merah (Phaseolus vulgaris L.) dan tepung konjac (Amorphophallus oncophillus). Jurnal Teknosains Pangan 3(1): 67.

Raman, M., Ambalam, P., dan Doble, M. 2016. Probiotics and Bioactive Carbohydrates in Colon Cancer Management. Springer, New Delhi.

Rincon, A. M. dan Padilla, F. C. 2004. Physicochemical properties of breadfruit (Artocarpus altilis) starch from Margarita island Venezuela. Archivos latinoamericanos de nutricion 54(4): 449-456.
Rosell, C., Santos, E. dan Collar, C. 2010. Physical characterization of fiber-enriched bread doughs by dual mixing and temperature constraint using the Mixolab. European Food Research and Technology 231: 499634.

Rusilanti dan Kusharto, C. M. 2007. Sehat dengan Makanan Berserat. AgroMedia Pustaka. Jakarta.

Sobari, E. 2018. Teknologi Pengolahan Pangan. ANDI OFFSET. Yogyakarta.

Sunarwati, D. A. 2011. Pengaruh substitusi tepung sukun terhadap kualitas brownies kukus. Naskah Skripsi S-1. Fakultas Teknik Universitas Negeri Semarang, Semarang.

Suprapti, L. M. 2002. Tepung Sukun: Pembuatan dan Pemanfaatannya. Kanisius. Yogyakarta.

Surampudi, P., Enkhmaa, B., Anuurad, E. dan Berglund, L. 2016. Lipid lowering with soluble dietary fiber. Current Atherosclerosis Reports 18(2): 75.

Suryanti, V., Rumingtyas, Y. S. dan Kusumaningsih, T. 2017. Physicochemical properties of dietary fibers from Artocarpus camansi fruit. International Conference on Food Science and Engineering 193/1/012012.

Sutartio, Y. 2018. Kualitas non flaky crackers dengan kombinasi tepung kacang merah (Phaseolus vulgaris L.) dan serbuk daun kelor (Moringa oleifera Lamk.). Naskah Skripsi S-1. Fakultas Teknobiologi. Universitas Atma Jaya Yogyakarta, Yogyakarta.

Tiwari, B. K., Gowen, A. dan McKenna, B. 2011. Pulse Foods: Processing, Quality and Nutraceutical Applications. Elsevier. London.

Utama, C. S., Zuprizal, Hanim, C. dan Wihandoyo. 2018. Isolasi dan identifikasi bakteri asam laktat selulotik yang berasal dari jus kubis terfermentasi. Jurnal Aplikasi Teknologi Pangan 7(1): 1-6.

Utama, C. S., Zuprizal, Hanim, C. dan Wihandoyo. 2018. Isolasi dan identifikasi bakteri asam laktat selulotik yang berasal dari jus kubis terfermentasi. Jurnal Aplikasi Teknologi Pangan 7(1): 1-6.

Waryat, Yanis, M. dan Handayani, Y. 2014. Diversifikasi pangan dari tepung sukun untuk mengurangi konsumsi tepung terigu di Kepulauan Seribu, Provinsi DKI Jakarta. Buletin Pertanian Perkotaan 4(1): 13-19.

Widowati, S. 2009. Prospek sukun (Artocarpus communis) sebagai pangan sumber karbohidrat dalam mendukung 
J.Gipas, November 2020, Volume 4 Nomor 2

ISSN 2599-0152 eISSN 2599-2465

http://jos.unsoed.ac.id/index.php/jgps

diversifikasi konsumsi pangan. Artikel edisi 56/XVIII/Oktober-Desember.

Wildman, R. E. C. 2007. Handbook of Nutraceuticals and Functional Foods. CRC Press. New York.

Winarno, F. G. 1997. Kimia Pangan dan Gizi. Gramedia Pustaka Utama. Jakarta. 